\title{
Performative entrepreneurship: identity, behaviour and place in adventure sports Enterprise
}

\section{Stephen Dobson ${ }^{1} \cdot$ Pete McLuskie ${ }^{2}$}

Published online: 25 April 2020

(C) The Author(s) 2020

\begin{abstract}
This research explores entrepreneurial identity and place in adventure sports within the emerging field of sports entrepreneurship. A growing body of literature has established the broad parameters of sports entrepreneurs mainly within the fitness sector. This study applies a performative entrepreneurship lens to explore the embedded nature of identity, behaviour and place amongst mountain bike (MTB) trainers and guides. This qualitative study is based around interviews with six trainers/guides conducted via online forums as well as participatory observations made on a group ride and of a communal response to the natural environment through trail building. Findings illustrate that unlike the fitness sector where there is a more established market and where entrepreneurs often move from employment to self-employment within the sector, the MTB adventure sports entrepreneur operates in a less formalised market resulting in less formal strategic planning. 'Place' is an important factor in the performative nature of enterprise in this study and it is clear that it is through lifestyle entrepreneurship that the individuals are 'performing' identity.
\end{abstract}

Keywords Sports entrepreneurship · Performativity · Cycling · MTB · Place

\section{Introduction}

The purpose of this article is to build a nuanced picture of entrepreneurial identity through the exploration of an emerging and niche area of sports enterprise. In doing so the authors valorise qualitative and more personal accounts as vital in building

Stephen Dobson

s.dobson1@leeds.ac.uk

Pete McLuskie

ab2893@coventry.ac.uk

1 School of Performance and Cultural Industries, University of Leeds, Leeds, UK

2 International Centre for Transformational Entrepreneurship, Coventry University, Coventry, UK 
awareness and initial understanding of less researched phenomena. With a focus on lifestyle entrepreneurship this study questions traditional notions of entrepreneurial activity as emerging from the enactment of intention or planned behaviour. Here, the nascent entrepreneur is embedded within a cultural 'scene' and their subsequent enterprising behaviour is much more emergent and performative than arguably many traditional approaches might assume. Dana and Dana (2005) argue that the predominance of traditional hypothetico-deductive approaches in entrepreneurship research tend to privilege intentionality due to the linear nature of deductive reasoning and so may serve to simplify what is, in reality, a much more emergent, reciprocal, and performative process. Here we are concerned with lifestyle entrepreneurial behaviour in an adventure sports setting and use the lens of performativity to help surface the vital role of 'place' in identity formation. This is the informal and grassroots world of mountain-bike (MTB) training and guiding as a sub-field of the wider area of adventure sports (which may include surfing, skateboarding, BMX, climbing etc). Adventure sports are often characterised by a strong lifestyle association as well as informal networks of participants (Farmer 1992). A relative lack of formal infrastructure means that these sports are regularly developed through grassroots actions and modest local funding and as such require a high degree of entrepreneurial behaviour from those established members of the social networks who act as catalysts and coordinators (Dobson 2015). Gherardi and Nicolini (2005) refer to this in relation to Actor Network Theory (ANT) in terms of the 'entrepreneur' being a powerful or charismatic actor who is capable of mobilising local resources.

MTB has experienced rapid growth in popularity over the past 20 years (Independent 2014). Although seeing a dip in sales around a decade ago, current and future forecasts for uptake globally remain strong "One trend in the market is mountain biking tourism [which] acts as a catalyst for economic development" (PRNewswire 2017). A significant driver in the market is described by the above report as "an increase in accidents and crashes, and related injuries [ ...] Although various companies have developed safety equipment to enhance the safety of the bikers, they are still prone to both minor and major accidents as they are unaware of the terrain ahead". For this reason, guiding and training is emerging as an important opportunity for enthusiasts and lifestyle sports entrepreneurs to offer a valuable service in this growing market.

A key shift in the formalisation of MTB sport may be seen therefore in the growth of those offering professional training, guiding and the development of nationwide trail centres (Dobson 2015). The Tourism Scotland Report (2017) estimated the economic impact of the MTB sector as being worth $£ 257 \mathrm{~m}$ in sales with the potential to rise to $£ 405 \mathrm{~m}$ by 2025 . Cycling and MTB in the context of tourism and outdoor recreation has had a considerable impact on expanding markets and economic growth, particularly in rural areas (Rogers \& Woodhouse 2015). Additionally, MTB has been discussed in the context of the growing 'experience' economy. According to Gibbs \& Holloway (2017) 'Experience landscapes emerge from a reorientation of existing landscapes and land uses towards the needs of particular activities and can be part of a multi-functional landscape in which other economic and leisure activities persist' (p.2). For those entrepreneurs who have emerged to provide an adventure experience, landscapes and place are not just intrinsic to their enterprise offer, they are part of their own identity; and it is through this intimate knowledge of the landscape that the value of the guide leader is expressed. 
Given the important economic contribution of cycling, MTB, and trails to rural economies and tourism it could be argued that ride leaders and trainers have the potential to play an important role in the entrepreneurial eco-system. However, knowledge of this area of sports enterprise and entrepreneurship, as a sub-field of the general area of sports management, is extremely limited. Lera-López and Rapún-Gárate (2005) outline two distinct schools of thought in sports management research with scholars from the US focusing particularly on economic impacts of professional sports whereas European scholars have considered contribution to health and well-being as well as employment and GDP (Gratton, and Taylor, 2000). Ratten (2010a) explores the future of sports management in academic research underlining the value of social responsibility, philanthropy and entrepreneurship. Within this setting this study aims to underline the importance of place and identity in many areas of sport, but particularly in the field of adventure sports. By underlining the cultural context in this study, as well as the creative and highly personal relationship with the landscape, a key contribution is to offer an indistinct picture where boundaries are blurred between enterprise, sport, and the cultural and creative industries. By broadening the scope of sports management to focus on sport service and sports spectacle it enables the researcher to encompass the emotional, symbolic and environmental dimensions of the sector (Ratten 2010a). Understanding the role of 'place' requires an immersed and qualitative research approach to lifestyle entrepreneurship so as to build rich pictures of localised participation to compliment macro-quantitative or economic studies. Entrepreneurs associated with these emerging sports do not necessarily perceive themselves as such or may struggle to formalise their business models due to lack of entrepreneurial identity. Instead, entrepreneurs in this somewhat non-traditional sector may view their enterprise more as a means to maintain their role and status in a lifestyle community, thus primarily using the activities as a means to perpetuate their engagement with the sport and reinforce connection to the natural environment within which they operate.

\section{Lifestyle, sports, and entrepreneurial ways of being}

Self-employment has been a growing feature of the UK economy representing a shift from $12 \%$ of the workforce in 2001 to $15.1 \%$ in 2017 (ONS 2018). Significant features of this shift include an increase in part-time self-employment and a sharper increase in male self-employment (ONS 2018). Findings have also identified lower net incomes from self-employment compared to employment (ONS 2018). Motivators toward selfemployment are therefore not always related to higher income potential. A number of authors note the greater sense of satisfaction that comes with self-employment (Lange 2012; Hessels et al. 2017) and the higher levels of personal autonomy which become motivating factors (Kautonen et al. 2015; Kautonen et al. 2017). For the lifestyle entrepreneur, or even enterprising enthusiast, autonomy and personal reward are significant drivers and potentially out-weigh more traditional rational economic motivation for enterprise start-up. 'Living in the area', 'being their own boss', and 'doing interesting work' were identified by Thomas et al. (1997) as variables with much greater significance than economic motivation. These findings are replicated in many international studies into lifestyle entrepreneurial intention (Dewhurst and Horobin 1998; Morrison et al. 1999; Thomas, 2004; Deakins and Freel, 2006). Marchant and Mottiar (2011) in their study of surf tourism highlight Kaplan (2003) in defining 
lifestyle entrepreneurs as those "who design the entrepreneurial activity around their preferred lifestyle and personal circumstances" (Marchant and Mottiar 2011, p172). From the outset therefore, we may appreciate that the notion of 'entrepreneurs' and 'entrepreneurship' are broad and contested categories to apply here. For many, entrepreneurship is related to business start-up and organisation creation (Gartner 1988), however wider perspectives recognise the process in terms of opportunity identification and value creation leading to economic activity, which does not necessarily involve starting a firm (Davidsson et al. 2006; Shane and Venkataraman 2000). Attempts have also been made to understand the entrepreneurial process in terms of 'intention' and 'character', arguing that entrepreneurial action is the result of planned behaviour resulting from intention and from an inclination towards entrepreneurial endeavour (Ajzen 2002, 1985). However, studies have also acknowledged a lack of entrepreneurial intention with subjects exhibiting influences from other factors such as serendipity (Varamaki et al. 2016). Characteristics and trait research can elucidate why and how people become engaged in entrepreneurial behaviour (Bridge et al. 2003; Florin et al. 2007). For example, entrepreneurs are regarded as possessing a number of shared attributes including: a need for achievement, internal locus of control, tolerance of ambiguity and risk, as well as self-confidence and creativity (Marques et al. 2013; Vrdoljak and Dulcic 2011). The traits approach has however been criticised (Cools and Van den Broeck 2007). For example, Thompson (2009) notes that many people who exhibit appropriate entrepreneurial characteristics may never express intent or go on to engage in entrepreneurial activity. However, these accounts of entrepreneurship do not represent for all forms of enterprising and entrepreneurial activity. Social entrepreneurs for example are defined by their focus on generating social outcomes, as opposed to economic and financial objectives (Dees 2004). This in turn affects how social entrepreneurs assess and act upon opportunities as well as their motivations for pursing them, which are related to their social mission or quality of life rather than wealth creation (Kautonen et al. 2017; Hartigan, 2006).

In considering the emerging body of research on sports entrepreneurship within the broader areas of entrepreneurship and sports management, Ratten (2010b) describes a sports entrepreneur as "someone who organizes, operates, and assumes risk for a sports-related business venture" (p.560). Ratten (2012) defines sports entrepreneurship broadly as "any innovative activity that has a sports objective [ ... Sport entrepreneurship involves the processes, practices and decision-making activities that lead to the development of products, services or markets" (p65). Bill (2009) asks whether 'sports entrepreneurship' is distinctive enough to distinguish either the entrepreneur or the enterprise from other mainstream entrepreneurial activities before suggesting that they can be described as "an individual who has the tacit industry-specific knowledge (e.g. personal trainer) and/or general business knowledge (e.g. football club owner), innovatory capacity and creative spirit to spot and generate openings within the sport sector in order to realise a market opportunity" (Bill 2009: 23). However, in these accounts sports entrepreneurs are distinguished by the sector and their industry knowledge rather than strategies, behaviours, or personal values - as would seem more appropriate for this study. Several researchers note the social motivation of sports entrepreneurs who may be driven by community or social goals rather than financial gain and profit (Ratten 2011, 2012; Hemme et al. 2017; Ratten and Jones 2018). While there is strong evidence that sports entrepreneurs are socially engaged, nevertheless it 
has been noted that this focus is related to the specific industry, lifestyle context, or in policy areas where social benefit is a key criterion for accessing public funding (Peterson and Schenker 2017). Furthermore, it has been noted that formal recognition of entrepreneurial identity is often absent in the sector (Brown 1996). Examining entrepreneurship in the field of sports fitness, Brown found that few of the participants perceived themselves as entrepreneurs: "Entrepreneurship was associated with hiring employees and providing a tangible product" ( $\mathrm{p} . \mathrm{V})$. Furthermore, there is a view that sports entrepreneurs rely heavily on social capital and networks to build stakeholders and enable innovation (Ratten, 2010b, p.559).

Hemme et al. (2017) explore how sports entrepreneurs, particularly in the fitness sector, strategize and pursue competitive advantage in a non-traditional industry. Whilst sharing many similarities with entrepreneurs in other sectors, fitness/sports entrepreneurs are described as affected by a variety of factors associated with non-conventional industries. They identify four key themes that characterise the fitness/sports entrepreneur. First the 'process' characteristics of entrepreneurship which involves adjusting to and taking on a variety of roles. 'Strategic learning' reflects a propensity for a trial and error approach to enterprise development and as such the entrepreneur may be perceived as responsive to customer needs and sector challenges rather than implementing a formalised and longerterm business strategy. A third characteristic is a 'controlled dependency' which emphasises a reliance on a core network of people and communities. This in turn may be used to support and enable the fourth key theme: the entrepreneur and fitness/sports entrepreneurship as a form of social enterprise pursued for social ends rather than financial benefit (p.96). Furthermore, Hemme et al. (2017) note the lack of planning and goal setting that informs fitness/sports entrepreneurship linking it to Effectuation strategies as developed by Sarasvathy (2001) and Dew et al. (2009).

Despite the rise in popularity of adventure sports, both in terms of product sales and as a source of emerging lifestyle entrepreneurship around experience tourism, it has been argued above that more needs to be done to further develop the emotional, symbolic, and environmental dimensions in sports management research. Since this sub-sector is typified by lifestyle entrepreneurs who may be motivated more by the wish to maintain and build a cultural scene, to sustain a preferred lifestyle or, particularly in the case of this study, to preserve an emotional link to landscape and place, it is important to employ approaches which offer the researcher the opportunity to appreciate rich accounts of individual stories and local contexts. Through qualitative means this study aims to help characterise an under-researched area and support future work around adventure sports enterprise. By indicating the importance of the environment and place in the performative identity of such lifestyle entrepreneurs we also seek to valorise the role of wider qualitative approaches in building scholarly understanding.

\section{Research objectives}

From the review of existing theoretical frameworks relevant to the study, the following research objectives are formed to structure enquiry: i) Firstly, to what extent do cycling/ MTB ride leaders/trainers (as a form of sports/fitness entrepreneurship) identify as entrepreneurs? ii) What is the importance of place and landscape to the performance of identity? In addition, iii) do cycling/MTB ride leaders/trainers exhibit explicit strategic 
entrepreneurial business behaviours in terms of entrepreneurial intention, business planning, and strategy.

\section{Methodology}

\section{Philosophical background}

In familiarising ourselves with the research area prior to data collection, the authors observed that the nature of adventure sports enterprises relating to MTB guiding and training seemed highly informal and embedded in the local social networks related to the sport. The subjects did not seem to be driven by traditional notions of rational planned behaviour. Bruni et al. (2004) explore the intertwined notion of entrepreneurship and identity of 'self' (in the context of gender), and it is through the broad application of this lens of performativity that the authors felt there lay a closer theoretical fit:

"enacted as situated practices [...] As well as being an economic phenomenon, entrepreneurship can also be read as a cultural one. Entrepreneurial action is an archetype of social action and, as the institutionalization of values and symbols, it can be related to gender for a cross-reading of how gender and entrepreneurship are culturally produced and reproduced in social practices." (p406)

What this study draws from Bruni et al. is the notion of an entrepreneurship and lifestyle identity which is entwined, enacted and performed through practice. For adventure sports entrepreneurship, which is so embedded in lifestyle and place as MTB training and guiding, we therefore draw upon performativity (Butler, 1999) of identity as informing, and informed by, the nature of enterprise. As is outlined above, we might expect that in this sector entrepreneurial motivation and intention, process, strategic learning and planning are less formalised and blurred within the notion of enactment and the performance of identity. Traditional entrepreneurship models based upon economic rationality seem limited in this context since here the entrepreneur, their notion of enterprise, and their lifestyle identity are tacit, interwoven and indivisible. Such individuals acknowledge their proactiveness and enterprising nature but are likely to consider this entrepreneurial behaviour as embedded rather than distinct and identitydefining (Brown 1996).

The performative nature of entrepreneurship and identity is an emerging area of entrepreneurship literature (Phillips and Knowles 2012; Garud et al. 2014, 2017; Garud and Gehman, 2016) which considers that these "can never be a settled state of affairs, but instead must be considered as an ongoing journey" (Garud et al. 2017, p502). In this case enterprise and identity are performance acts, which in turn create the very stage for the performance. Bruni et al. (2004) consider identity as "the effect of a network of relations which give material form and stability to an artefact" (p407) and as such are informed by performative identity as offered by Butler (1999) and Bruni and Gherardi (2001). Identity Theory (IT) offered by Stryker and Burke (2000) and Stets and Burke (2000) also notes a reciprocity between identity and behaviour. However, as with more traditional approaches to entrepreneurship research, there is still an implied 
rationality in the IT process of 'identification' and the act of self-categorisation within the entrepreneurial context. Therefore, whilst acknowledging the notion of the continuous and reciprocal journey of identity and behaviour (as being intertwined and reinforcing) it is argued that IT still considers these through a rational lens. Sport entrepreneurship has been explored in the context of lifestyle where the motivation to start a business is driven by a desire to maintain or pursue a particular lifestyle choice related to individual passions, interests, and personal circumstances (Swan and Morgan 2016). Lifestyle entrepreneurs are generally understood to be less motivated by profit and business growth (Morrison 2006), and instead are seen to base decision-making on subjective needs and observations rather than objectives facts related to economic conditions and market opportunity (Dewhurst and Horobin, 1998). Other studies of lifestyle entrepreneurs have identified more complex entrepreneurial identities which recognise that 'lifestyle' may indeed be combined with commercially orientated goals (Bredvold and Skålen 2016).

\section{Methods}

This study adopts critically subjective, qualitative approaches to explore notions of entrepreneurial behaviour, identity and place through the lens of performativity. These involve: 1) semi-structured interviews with ride leaders/guides for whom the activity was either a partial or main source of income. This was based around interviews with six trainers/guides conducted via online forums; and 2) observation gained through participation to consider the space/place through which entrepreneurial behaviour is enacted and identity formed.

\section{Interviews}

Participants were recruited through online cycling forums and discussion groups. Recruitment took place over a period of around 4 months and participants either identified themselves in response to the call or were recommended by others in their network. The participants selected represent a geographic spread and are summarised below in Table 1.

Interviews were undertaken with the participants using an open, semi-structured format but with follow-up questions where appropriate.

Table 1 Participant Profile

\begin{tabular}{lll}
\hline Age & Sex & Occupation \\
\hline 53 & Male & Sports Coach \\
46 & Male & Entrepreneur, MTB skills and fitness coach, Artist \\
51 & Male & Ride Leader and Coach, Military \\
47 & Male & FT Self-employed builder, PT MTB coach and guide \\
43 & Male & MTB guide, coach, retained firefighter \\
39 & Male & Events organiser and consultant \\
\hline
\end{tabular}




\section{Participatory observation}

Prior to the New Geography of the 1960s, traditional treatment of space was dominated by "providing a narrative account of what happens where." (Conolly and Lake 2006, 8). This Cartisian perspective was based on the thought of seventeenth Century philosopher and mathematician René Decartes who considered a split between mind and body (mind-body dualism). This led to notion of the 'subject' and 'object' and, in this sense, the external world was independent of 'subjective' reality. Merleau-Ponty (1962) and Bourdieu's (1984) 'habitus' explore spaces as embodied and symbolic. These humanist approaches in geography introduced a multitude of social and phenomenological perceptions of space as media through which we are produced and reproduced. Henri Lefebvre (1991) explored the interactions between physical, mental and social space, considering Bourdieu's 'habitus' as our 'mode of being' (1991, 259): "the whole of social space proceeds from the body" (1991, 405). Therefore, the phenomenological appreciation of landscape is important in this study for relating the experiential with the cartographic. In referring to the phenomenology of landscape, it is outlined that "landscape is synergistic and its parts and interconnections make an environment into a whole" (i Font 1993, 163). In contrast to positivist approaches, phenomenology assumes that the researcher cannot be detached from their own assumptions and beliefs (Hammersley, 2000). The focus is on description of the encountered phenomena with meaning extending from the researcher's direct engagement. Hycner (1999, p. 156) outlines that "the phenomenon dictates the method (not vice-versa) including even the type of participants". Here purposive sampling is favoured since the researcher is required to look for those who "have had experiences relating to the phenomenon to be researched" (Kruger, 1988 p. 150). In line with the approaches described above, the researcher made observations whilst participating in a group ride and with a second group's trail building activity.

\section{Results and discussion}

When asked about the proportion of time spent conducting services such as MTB ride leading, training and coaching the participants indicated that predominantly this was a part time activity. The responses ranges from $10 \%$ to $70 \%$ of their time. Supplementary income came from a variety of sources such as working with brain injury victims, the construction industry, military, and events organisation. The nature of the training and coaching services that they provide was described by each in terms of quality experience and as such supports with the notion of experience tourism and lifestyle sports as a key part of the offer. The bespoke nature of coaching was highlighted: Providing sports coaching from prebuilt packages to bespoke (P1) and Assisting mountain bikers who wish to convert their challenges into abilities (P2). As outlined by Gibbs and Holloway (2017) the interviewees position themselves within the local 'experience economy' as they describe their role in terms of trainer and skills coach but also as a guide to the local landscape. In this sense they are developing abilities but importantly are providing an experience of 'place': [I] guide people around the best trails in the peaks. Tailoring routes to suit ability. Coach core fundamentals to new to intermediate riders to help them progress and iron out bad habits. This includes bike set up, teaching navigation 
using maps and compass, as well as technology, to make riders safer in the outdoor environment (P4). Interviewees also describe their key customers in terms of all skills levels with a particular customer base of novices and beginners: All levels of mountain bikers except expert/pro. My passion and attentiveness. Ability to convey thoughts and ideas and to describe a number of different ways if one way doesn't work. Very small groups or one on one learning (P2). The experience offered is therefore one of revealing a 'hidden' landscape but also of a bespoke and personalised connection to it.

Personal attention, authenticity and passion are terms used to describe the kind of sports experience the participants are aiming to provide: Main customers are the local road racing team, who are wanting to branch out into MTB, and are struggling with posture, movement, position etc. All women group coaching, as cycling partners usually lack the skills and or patience to encourage them correctly. My services are very personalised, feedback suggests everyone benefits and feels a better, more confident rider for it (P4). The language used here is in many ways reminiscent of fitness and lifestyle coaching who seek to develop the individual but also of the tour guide who is providing a "guide plus" role of consumer emersion (Hansen and Mossberg, 2017). The entrepreneur is both selling and facilitating a life-style entwined between a particular kind of consumer behaviour and place whilst reinforcing their own identity through this:

I think they like the fact that we're authentic, they know we love cycling too and they know we go out of our way to create good rides and good experiences for them [ ... ] the reason that I believe they think it's authentic is because our events are small enough that people meet me and if they have a question or comment (either face to face or digital) then they get a response from me in person. I think that's a mark of authenticity (P6).

The question as to whether the interviewees identified as being an entrepreneur was mixed with two participants responding that they did not identify as being entrepreneurs, three responding that they did, and one with a reluctant: I suppose so (P5).

In order to explore other identity characteristics, the participants were asked if they considered themselves creative. All participants responded that they did indeed consider themselves creative, for example: (P2) Yes, Creative solutions to constant trail movements and riders abilities (P5) Some creativity is required in lots of aspects of what we do, whether it's route design or just having a point of view on the work of a graphic designer or creating the event website (P6). Creativity therefore was considered something intrinsic to this form of sporting activity, particularly as natural hazards and obstacles were seen to require creative solutions to overcome as landscape characteristics may change from day-to-day in relation to different rider abilities and also environmental and weather-related factors. The changing nature of place and the creativity required to engage with this was therefore an important theme. There was a much closer association with the notion of being creative that that of entrepreneur amongst participants despite the activities being in some cases quite a significant contribution to finances.

The participants were asked if and how they planned their activities as a business and whether they felt they had formulated a strategy. It is interesting to note here that all participants described their actions in terms of being organic, responsive and evolving: No. I prefer to allow natural evolution of my business (P1), It kinda grew organically over the last 11 years. Only really formalised it recently (P2), None really! (P3), No plan to start 
with, but long-term plan is to run a hostel with my partner, and guide and coach from there (P4). I guess the short answer is that we have a direction. Sometimes something more interesting, lucrative or just plain necessary intervenes in the way and we adjust. There's definitely no quantifiable growth strategy though (P6). However, despite a lack of formal strategy development, all participants acknowledged the importance and necessity of networking and so we might consider this a mitigating factor for lack of emphasis on business strategy. (None of the participants report having received any formal business training). Being an active networker enables the entrepreneur to remain adaptive and responsive to short-term shifts in local customer base (Dobson et al. 2013). Whilst most respondents described themselves as naturally good at networking, participant 6 outlined their attempts to overcome a lack of networking confidence. This exhibits a view that networking and developing a 'community' is an important element of success in adventure sports entrepreneurship: Active, yes. Natural, no. I read a book called Quiet by Susan Caine, and understood a lot better why I find that stuff so exhausting even though I can be reasonably good at it (P6), Riders join my community where they interact, ride together and learn. (P2).

Whilst the participants had not received (or sought) any formal business training they were highly qualified in all areas of ride instruction and safety, navigation and survival (MIAS, TL6, MBI, BC coach, ABCC). When asked about whether barriers existed to engage with training one participant referred to financial barriers: All depends on the circumstances. A fiver is too much on days I don't have a fiver. The entry cost to anything is often a barrier. But ongoing training is a constant money pit. I spend at least $£ 1000$ per year on $C P D(P 1)$. Whilst the participants generally did not perceive significant barriers to undertaking training qualifications it was noted that barriers did seem to exist from lack of family role models and exposure at school being cited as key: I think there are huge barriers to people being entrepreneurial though. It was never mentioned in school, I don't have any familial role models in that respect and so that's made it fell pretty lonely from time to time (P6). Since the nature of entrepreneurial activity here is aligned with lifestyle and adventure sports we hypothesise a limiting factor as being the comparative lack of family continuity, although this is likely to change as the sport matures over generations.

In terms of identity, whilst all respondents considered themselves to be 'creative' there appeared to be greater resistance to the term 'entrepreneurial'. Throughout the discussions it seemed clear that business development and growth were not key drivers and the acknowledgement of opportunity was not a traditionally entrepreneurially motivated. Instead, the way that interviewees described their activities was much more aligned to the creative and social enterprise where "mission-related impact becomes the central criterion, not wealth creation" (Dees 2017, p40). The value and impact of their services emerges as paramount with suggestions that the interviewees are motivated by improving the confidence of their customers and the positive social and community impact of cycle training and ride leading. In addition, two respondents specifically refer to their own passion and love of cycling which is in turn valued by their customers. 'Passion' has been suggested by several researchers to be a key element driving entrepreneurial behaviour (Hemme et al. 2017; Cardon, et al. 2005), but with creative and especially social enterprise the entrepreneur is especially characterised by seeking:

"a sound understanding of the constituencies they are serving. They make sure they have correctly assessed the needs and values of the people they intend to 
serve and the communities in which they operate. In some cases, this requires close connections with those communities. " (Dees 2017, p41)

The interviewees very much saw themselves as part of the ride community of a place; a leader, coordinator, facilitator, and mentor. They displayed pride in knowing the local landscape and trails and being able to provide a supportive and bespoke experience. These characteristics account for the motivations for starting their enterprises and align with the observations of social entrepreneurs made by Dees. However, in addition to the social missions described, the interviewees also exhibited characteristics of lifestyle entrepreneurs in the sense that their activities enabled them to simply 'do what they enjoy' and therefore reinforce identity through their behaviour. Fostering self-confidence in others was cited by all participants as a significant motivational factor and none of the respondents mentioned market opportunity or financial gain as motivators.

Throughout the interviews there was also a clear and ubiquitous dimension of 'place'. MTB is necessarily a sport embedded in landscape and as Bruni et al. (2004) suggest, the performativity of identity is embedded in a network of social relations through which identity is performed and constructed.

\section{Ride participation observations}

A group gathers at a popular tourist location in the Peak District and wait whilst the ride leader (P1) checks the bikes over to make sure the riders have suitable equipment and provides a safety briefing. This is done professionally but informally and it is clear that P1 wishes to build a rapport and potentially attract repeat custom. Immediately P1 is keen to underline that they will introduce the group to little known areas of the local landscape, as such they are both demonstrating their value to the group as a guide and reinforcing their own status as an expert. The knowledge they possess is clearly developed over many years from the stories of adventures past that P1 entertains the group with as the ride progresses.

There are many challenging sections to the ride which takes place over a six hour period. This requires $\mathrm{P} 1$ to offer advice on technique and build riders' confidence through coaching methods. P1 describes what is ahead and suggests body positioning to best prepare for the terrain. The views and landscape features that are revealed through the routes chosen by P1 are spectacular and are very much part of the region's 'experience' offer (as described by Gibbs and Holloway 2017). P1 reinforces their own connection to this landscape with stories from childhood. This engenders a sense of privilege amongst the ride participants through exposure to special local knowledge. Cheong and Miller (2000) also note this in their own work on power and tourism:

"Guides are not always able to rely on repeat customers, but they do depend on the tips and word-of-mouth advertising of satisfied tourists. They construct the gaze through their special expertise, esoteric "local knowledge", and abilities. Thus, they demonstrate their worth by being able to converse with tourists in their language, by knowing popular trails and interesting fora and fauna, by recounting cultural and architectural histories, by knowing local customs, and so forth." (p372) 
Landscape is both appreciated visually but is also responded to creatively. As an adventure sport, MTB is not just about moving from A to B, it is also about finding exciting and creative ways of moving through sometimes challenging terrain. The local names for parts of trails and obstacles are given by P1 and the riders are encouraged to challenge themselves to negotiate the landscape in a positive and attacking manner. Language such as 'flow', 'continuity', 'response' is used by P1 as the riders traverse the terrain to reinforce the aesthetic and creative choices made by riders in cornering and descents. The focus is very much on the quality of the riding experience, much like a surfer seeking to ride in partnership with nature.

About halfway through the ride, two tourists who have hired bikes ask if they can join the group. They are treated to an immersive experience of the landscape and many aspects of local history are now brought into P1's guiding narrative since the tourists had travelled from out of the region to be here. Places to eat and stay are recommended by $\mathrm{P} 1$ and the tourists comment on the value of local knowledge as they are introduced to places 'off the beaten track'.

It is clear from this observation that P1 is acting entrepreneurially. This is a significant source of income and they rely on repeat custom and as such must vary the trails, or the manner through which the terrain is ridden, to ensure variety as well as selling the region as a tourism destination. In many ways this lifestyle entrepreneur is selling a performance within an experience of place, more so than simply offering a coaching function. In this sense they are perhaps are more closely aligned to the cultural and creative industries than sports enterprise due to the intrinsic value of creativity and aesthetic experience in their value proposition.

\section{Trails and their use as creative spaces}

A second observation 2 mo later does not involve the interview participants but instead witnesses illicit trail building at a secret riding location popular with locals in a patch of urban woodland. It is here that we find the direct creative modification of an already popular riding location to reinforce an experience of 'flow' and riding transitions. The trail that is cut very much reflects the riding style of the trail builder and especially their imagined riding 'lines'. These are highly sculptural interventions that introduce a dynamic aesthetic of movement through the densely wooded space, and are reminiscent of the lines a skier might adopt when creatively descending a mountainside. The trails are built by a number of volunteers of varying experience and reinforces the status of the person leading the building process. Trails may be illicitly cut through private woodland to augment and enhance the landscape. These represent the lead trail builder's creativity and vision, their riding style and personality which are literally embedded and built into the landscape in reciprocating partnership. To those accustomed to 'reading' the way the landscape has been shaped, in order to encourage a particular way of moving through it, these creative choices can be like the signatures or 'tags' of graffiti artists.

This is a network bonding experience which also reinforces the exclusivity of localised, specialist knowledge since many informal trails (away from official trail centres) are 'secret spots' due to their illicit status. It is through these kinds of grassroots activities that the charismatic 'entrepreneur' emerges (Gheradi and Nicolini 2005) in this adventure sports contexts and their identity, as embedded in landscape, is 


\section{Identity}

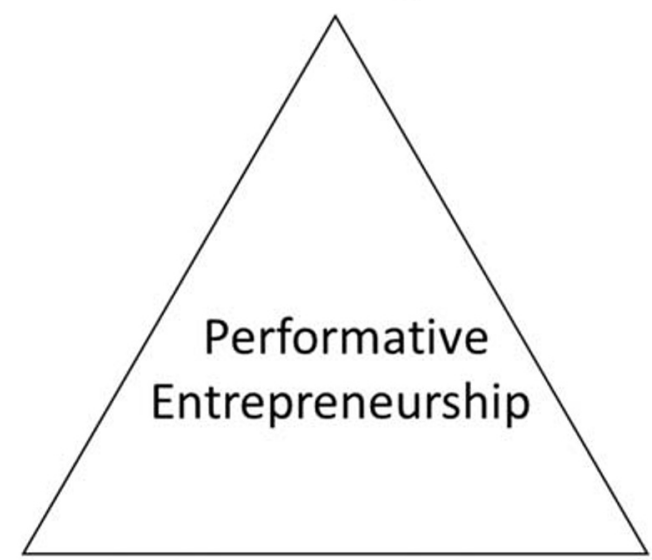

\section{Behaviour}

\section{Place}

Fig. 1 A framework for Performative Entrepreneurship

reinforced through such performative acts. Landscape therefore is not merely a location where things happen or a backdrop to human activity, nor is it solely an instrumental asset through which capitalism is played out. Landscape is the indivisible combination of environmental, human, and economic spheres (Selman 2012). In this sense, the performance of identity is enacted via behaviours and the human-nature space through which it is performed (i.e. the landscape). Therefore, we extend the identity/behaviour dualism offered by Bruni et al. to inform a reading of performativity and entrepreneurship within the triad of identity/behaviour/place (Fig. 1).

Whilst subjective and qualitative, the observations provide an important means to sensitize researchers to what is otherwise an extremely organic and performative environment through which rational opportunity identification is certainly less clear or formalised. The 'entrepreneur' in this sense gains a certain status through peer acknowledgement of their contribution to a local cultural 'scene'. Opportunities to commercialise activities, in the case of the ride leaders, seems to start in an 'ad hoc' manner and is pursued as a way of reinforcing a non-entrepreneurial (lifestyle) identity. In fact, the success of these lifestyle entrepreneurs relies on them restraining their own entrepreneurial identity as this is seen to be at odds with the community that they operate within. They wish to be perceived as authentic and embedded in this lifestyle and community rather than acting strategically or motivated by revenue opportunity. Our work suggests a form of sports enterprise which is both social and lifestyle but also place dependent.

\section{Conclusions}

This study explores the entrepreneurial identity of MTB trainers and guides using the perspectives of performativity and place to construct a model that has greater resonance in this context than established accounts of entrepreneurial identity. It is clear that the subjects of this study were not driven by market opportunity and did not actively pursue 
business growth and development (Gartner 1985, 1988). Elements of social entrepreneurship and social impact are evident in the comments from the trainers/guides which align with emerging studies from the fitness and sports sector (Ratten and Jones 2018). However, what is clear from the responses is that the respondents are very much interested in pursuing their own passions rather than social impact per se, which suggests a 'lifestyle' entrepreneurial identity (Kaplan 2003; Morrison 2006).

To this extent we may draw upon multiple models to help explain the identity of the MTB trainer/guide as entrepreneur, however, we argue that a more nuanced and perhaps holistic understanding of the MTB trainer/guide community results from applying a lens which incorporates 'performance' and 'agency' as dispersed amongst actors in the eco-system or network. This includes the non-human actor of landscape (or 'place') with which the performance of entrepreneurial identity is enacted, enabling the resultant entrepreneurial action. This leads to deeper insights into the entrepreneur not as a powerful actor mobilising resources for a specific end, but as: "the partially planned and partially fortuitous coming together and alignment of "social worlds"” (Gherardi and Nicolini 2005: 5).

Furthermore, this study provides useful insights into the mind-set and character of the entrepreneurs in question. In this sense they are not the classic risk-takers who are opportunity-driven and motivated solely by the search for economic returns. Neither are they independent of their context or governed by intention and strategic drive. Instead it is the network of human and non-human actors which enable entrepreneurship to emerge. It is evident from this study that the notion of 'entrepreneurial intention' is somewhat limited in explaining participant behaviour, which is so entwined with lifestyle, as found in adventure sports contexts. However, further research is needed into the wider network of relations to gain better insights into how enterprises emerge and develop and to which areas of sports enterprise this is most applicable.

\section{Limitations of the study}

Due to the emerging nature of training provision in the sport the number of participants is relatively small $(n=6)$ however these represent a reasonable geographic spread in the UK. There is also an age and gender bias in the study which currently reflects the bias in this field of enterprise. It is interesting to note a somewhat mismatch between the level of MTB as a global industry as identified through the units sold and market share of the broader cycling industry, and the nature and formalisation of training provision which remains relatively informal and unplanned.

\section{Further research}

Whilst this area of adventure sports entrepreneurship is represented by a modest training sector, it is important to understand the emerging development of lifestyle enterprise such as this for wider application - both across other adventure sports, but also into fields such as cultural and creative industries where similar notions of community 'embeddedness' (Jack and Andersen 2002) may influence artist/ entrepreneurial identity. 
Open Access This article is licensed under a Creative Commons Attribution 4.0 International License, which permits use, sharing, adaptation, distribution and reproduction in any medium or format, as long as you give appropriate credit to the original author(s) and the source, provide a link to the Creative Commons licence, and indicate if changes were made. The images or other third party material in this article are included in the article's Creative Commons licence, unless indicated otherwise in a credit line to the material. If material is not included in the article's Creative Commons licence and your intended use is not permitted by statutory regulation or exceeds the permitted use, you will need to obtain permission directly from the copyright holder. To view a copy of this licence, visit http://creativecommons.org/licenses/by/4.0/.

\section{References}

Ajzen, I. (1985). From intentions to actions: A theory of planned behaviour. In J. Kuhl \& J. Beckmann (Eds.), Action control (pp. 11-39). Berlin: Heidelberg: Springer.

Ajzen, I. (2002). Perceived behavioral control, self-efficacy, locus of control, and the theory of planned behaviour. Journal of Applied Social Psychology, 32(4), 665-683.

Bill, K. (2009). Sports entrepreneurship. In K. Bill (Ed.), Sport Management. Exeter: Learning Matters.

Bourdieu, P. (1984). Distinction. A social critique of the judgement of taste. Cambridge: Harvard University Press.

Bredvold, R., \& Skålen, P. (2016). Lifestyle entrepreneurs and their identity construction: A study of the tourism industry. Tourism Management, 56, 96-105.

Bridge, S., O'Neill, K., \& Cromie, S. (2003). Understanding Enterprise: Entrepreneurship and small business (2nd ed.). New York: Palgrave Macmillan.

Brown, L.A. (1996). Entrepreneurship in the fitness and sport industry. (Doctoral dissertation, University of British Columbia).

Bruni, A., \& Gherardi, S. (2001). Omega's story: The heterogeneous engineering of a gendered professional self. In M. Dent \& S. Whitehead (Eds.), Managing professional identities: Knowledge, performativity and the 'new' professional (pp. 174-198). London: Routledge.

Bruni, A., Gherardi, S., \& Poggio, B. (2004). Doing gender, doing entrepreneurship: An ethnographic account of intertwined practices. Gender, Work and Organization, 11(4), 406-429.

Butler, J. (1999). Gender trouble: Feminism and the subversion of identity. London: Routledge.

Cardon, M., Zietsma, S., Saparito, C., Matherne, P. B., \& Davis, C. (2005). A tale of passion: New insights into entrepreneurship from a parenthood metaphor. Journal of Business Venturing, 20(1), 23-45.

Cheong, S. M., \& Miller, M. L. (2000). Power and tourism: A Foucauldian observation. Annals of Tourism Research, 27(2), 371-390.

Conolly, J., \& Lake, M. (2006). Geographical information systems in archaeology. Cambridge: Cambridge University Press.

Cools, E., \& Van den Broeck, H. (2007). The hunt for the Heffalump continues: Can trait and cognitive characteristics predict entrepreneurial orientation? Journal of Small Business Strategy, 18(2), $23-42$.

Dana, L.P. \& Dana, T.E. (2005). Expanding the scope of methodologies used in entrepreneurship research. International Journal of Entrepreneurship and Small Business, 2(1), 79-88.

Davidsson, P., Delmar, F., \& Wiklund, J. (2006). Entrepreneurship as growth; growth as entrepreneurship. In P. Davidsson, F. Delmar, \& J. Wiklund (Eds.), Entrepreneurship and the growth of firms (pp. 21-38). Cheltenham, UK: Edward Elgar Publisher.

Deakins, D., \& Freel, M. (2006). Entrepreneurship and small firms (4th ed.). Basingstoke: McGraw Hill.

Dees, G. (2004). Social entrepreneurship is about innovation and impact, not Income. https://centers.fuqua.duke. edu/case/wp-content/uploads/sites/7/2015/02/Article_Dees_SEisAboutInnovationandImpactNotIncome_2003. pdf. Accessed 20 Apr 2020.

Dees, J. G. (2017). The meaning of social entrepreneurship. In J. Hamschmidt \& M. Pirson (Eds.), Case studies in social entrepreneurship and sustainability (pp. 34-42). Oxon: Routledge.

Dew, N., Read, S., Sarasvathy, S. D., \& Wiltbank, R. (2009). Effectual versus predictive logics in entrepreneurial decision-making: Differences between experts and novices. Journal of Business Venturing, 24(4), 287-309.

Dewhurst, P., \& Horobin, H. (1998). Small business owners. In R. Thomas (Ed.), The management of small tourism and hospitality firms (pp. 19-39). London: Cassell.

Dobson, S. (2015). Urban translations: Regeneration through the lens of actor-networking. Local Economy, 30(8), 944-960. 
Dobson, S., Breslin, D., Suckley, L., Barton, R., \& Rodriguez, L. (2013). Small firm survival and innovation: An evolutionary approach. The International Journal of Entrepreneurship and Innovation, 14(2), 69-80.

Farmer, R. J. (1992). Surfing: Motivations, values, and culture. Journal of Sport Behavior, 15(3), $241-257$.

Florin, J., Karri, R., \& Rossiter, N. (2007). Fostering entrepreneurial drive in business education: An attitudinal approach. Journal of Management Education, 31(1), 17-42.

Gartner, W. (1988). 'Who is an entrepreneur?' Is the wrong question. American Journal of Small Business, 26, $11-32$.

Gartner, W. B. (1985). A conceptual framework for describing the phenomenon of new venture creation. Academy of Management Review, 10(4), 696-706.

Garud, R., \& Gehman, J. (2016). Theory evaluation, entrepreneurial processes, and performativity. Academy of Management Review, 41(3), 544-549.

Garud, R., Gehman, J., \& Giuliani, A. P. (2014). Contextualizing entrepreneurial innovation: A narrative perspective. Research Policy, 43(7), 1177-1188.

Garud, R., Gehman, J., \& Tharchen, T. (2017). Performativity as ongoing journeys: Implications for strategy, entrepreneurship, and innovation. Long Range Planning, 51(3), 500-509.

Gherardi, S., \& Nicolini, D. (2005). Actor-networks: Ecology and entrepreneurs. In B. Czarniawska \& T. Hernes (Eds.), Actor-network theory and organizing. Copenhagen: Liber \& Copenhagen Business School Press.

Gibbs, D., \& Holloway, L. (2017). From experience economy to experience landscape: The example of UK trail centres. Area, 50(2), 248-255.

Gratton, C., \& Taylor, P. (2000). Economics of sport and recreation. London: Spon Press.

Hammersley, M. (2000). Taking sides in social research. London: Routledge.

Hansen, A. H., \& Mossberg, L. (2017). Tour guides' performance and tourists' immersion: Facilitating consumer immersion by performing a guide plus role. Scandinavian Journal of Hospitality and Tourism, 17(3), 259-278.

Hartigan, P. (2006). It's about people, not profits. Business Strategy Review, 17(4), 42-45.

Hemme, F., Morais, D. G., Bowers, M. T., \& Todd, J. S. (2017). Extending sport-based entrepreneurship theory through phenomenological inquiry. Sport Management Review, 20(1), 92-104.

Hessels, J., Arampatzi, E., van der Zwan, P., \& Burger, M. (2017). Life satisfaction and self-employment in different types of occupations. Applied Economics Letters, 24(6), 734-740.

Hycner, R. H. (1999). Some guidelines for the phenomenological analysis of interview data. In A. Bryman \& R. G. Burgess (Eds.), Qualitative research (Vol. 3) (pp. 143-164). London: Sage.

i Font, N. (1993). Toward a phenomenology of landscape and landscape experience: An example from Catalonia. In D. Seamon (Ed.), Dwelling, seeing, and designing: Toward a phenomenological ecology (pp. 159-180). New York: SUNY Press.

Independent (2014) When did it all start to go downhill for mountain biking? https://www.independent.co. uk/environment/green-living/when-did-it-all-start-to-go-downhill-for-mountain-biking-9202637.html (Last Accessed: 28 Sept 2018).

Jack, S. L., \& Anderson, A. R. (2002). The effects of embeddedness on the entrepreneurial process. Journal of Business Venturing, 17(5), 467-487.

Kaplan, J. (2003). Patterns of Entrepreneurship. Chichester: Wiley.

Kautonen, T., Gelderen, M., \& Fink, M. (2015). Robustness of the theory of planned behaviour in predicting entrepreneurial intent. Entrepreneurship Theory \& Practice, 39(3), 655-674.

Kautonen, T., Kibler, E., \& Minniti, M. (2017). Late-career entrepreneurship, income and quality of life. Journal of Business Venturing, 32, 318-333.

Kruger, D. (1988). An introduction to phenomenological psychology (2nd ed.). Cape Town, South Africa: Juta.

Lange, T. (2012). Job satisfaction and self-employment or personality? Small Business Economics, 38(2), 165-177.

Lefebvre, H. (1991). The Production of space. Oxford: Blackwell.

Lera-López, F., \& Rapún-Gárate, M. (2005). Sports participation versus consumer expenditure on sport: Different determinants and strategies in sports management. European Sport Management Quarterly, 5(2), 167-186.

Marchant, B., \& Mottiar, Z. (2011). Understanding lifestyle entrepreneurs and digging beneath the issue of profits: Profiling surf tourism lifestyle entrepreneurs in Ireland. Tourism Planning and Development, 8(2), 171-183.

Marques, C., Ferreira, J., Ferreira, F., et al. (2013). Entrepreneurial orientation and motivation to start up a business: Evidence from the health service industry. International Entrepreneurship and Management Journal, 9, 77-94. 
Merleau-Ponty, M. (1962). Phenomenology of perception. London: Routledge.

Morrison, A. (2006). A contextualisation of entrepreneurship. International Journal of Entrepreneurial Behaviour and Research, 12(4), 192-209.

Morrison, A., Rimmington, M., \& Williams, C. (1999). Entrepreneurship in the hospitality, Tourism and Leisure Industries. Oxford: Butterworth-Heinemann.

Office of National Statistics (2018) "Trends in Self Employment in the UK", available at https://www.ons.gov. uk/employmentandlabourmarket/peopleinwork/employmentandemployeetypes/articles/trendsinself employmentintheuk/2018-02-07 (Last Accessed: 15 March 2018).

Peterson, T., \& Schenker, K. (2017). Social entrepreneurship in a sport policy context. Sport in Society, 21(3), $452-467$.

Phillips, M., \& Knowles, D. (2012). Performance and performativity: Undoing fictions of women business owners. Gender, Work and Organization, 19(4), 416-437.

PRNewswire (2017). Global mountain bike market report 2017 - Forecasts to 2021. https://www.prnewswire. com/newsreleases/global-mountain-bike-market-report-2017-forecasts-to-2021-300561046.html. Accessed 20 Apr 2020.

Ratten, V. (2010a). The future of sports management: A social responsibility, philanthropy and entrepreneurship perspective. Journal of Management and Organization, 16(4), 488-494.

Ratten, V. (2010b). Developing a theory of sport-based entrepreneurship. Journal of Management and Organization, 16(4), 557-565.

Ratten, V. (2011). Social entrepreneurship and innovation in sports. International Journal of Social Entrepreneurship and Innovation, 1(1), 42-54.

Ratten, V. (2012). Sport entrepreneurship: Challenges and directions for future research. International Journal of Entrepreneurial Venturing, 4(1), 65-76.

Ratten, V., \& Jones, P. (2018). Future research directions for sport education: Toward an entrepreneurial learning approach. Education + Training, 60(5), 490-499.

Rogers, D. and Woodhouse, W. (2015). Economic Value of Outdoor, recreation house of commons library, debate pack no.2015/0082.

Sarasvathy, S. (2001). Causation and effectuation: Toward a theoretical shift from economic inevitability to entrepreneurial contingency. Academy of Management Review, 26(2), 243-263.

Selman, P. (2012). Landscapes as integrating frameworks for human, environmental and policy processes. In T. Plieninger \& C. Bieling (Eds.), Resilience and cultural landscape: Understanding and managing change in human-shaped environments (pp. 27-48). Cambridge: Cambridge University Press.

Shane, S., \& Venkataraman, S. (2000). The promise of entrepreneurship as a field of research. Academy of Management Review, 25(1), 217-226.

Stets, J. E., \& Burke, P. J. (2000). Identity theory and social identity theory. Social Psychology Quarterly, 63(3), 224-237.

Stryker, S., \& Burke, P. J. (2000). The past, present, and future of an identity theory. Social Psychology Quarterly, 63(4), 284-297.

Swan, C. D., \& Morgan, D. (2016). Who wants to be an eco-entrepreneur? Identifying entrepreneurial types and practices in ecotourism businesses. International Journal of Entrepreneurship and Innovation, 17(2), $120-132$.

Thomas, R. (2004). International perspectives on small firms in tourism: A synthesis. In R. Thomas (Ed.), Small firms in tourism: International perspectives (pp. 1-12). Oxford: Elsevier.

Thomas, R., Friel, M., Jameson, S., \& Parsons, D. (1997). The National Survey of Small Tourism and Hospitality Firms. Leeds: Leeds Metropolitan University.

Thompson, R. (2009). Individual entrepreneurial intent: Construct clarification and development of an internationally reliable metric. Entrepreneurship Theory and Practice, 33(3), 669-694.

Tourism Scotland (2017) 2020 Annual Report 2017, available online http://scottishtourismalliance.co. uk/uploads/TS2020_KPIs/Tourism\%20Scotland\%202020\%20Annual\%20Report\%202017\%20(1).pdf (Last Accessed, 20 April 2018).

Varamaki, E., Joensuu, S., \& Viljamaa, A. (2016). Starting up a firm or not: Differences in the antecedents of entrepreneurial intentions. Industry and Higher Education, 30(3), 239-249.

Vrdoljak, I. and Dulcic, Z. (2011) University students' entrepreneurial characteristics - Key for the future development. In: $9^{\text {th }}$ International Conference. Challenges of Europe: Growth and Competitiveness Reversing the Trends, Split, Croatia, 26-28 may 2011, (pp. 855-863). Split: University of Split Faculty of economics.

Publisher's note Springer Nature remains neutral with regard to jurisdictional claims in published maps and institutional affiliations. 